Global Conferences Series:

Social Sciences, Education and Humanities (GCSSSEH), Volume 3, 2019

The $1^{\text {st }}$ International Conference on Education, Social Sciences and Humanities

DOI: https://doi.org/10.326/hum0218

\title{
Teaching Skill Based on Effective Communication
}

\author{
Yuliani Nurani ${ }^{1(*)}$, Sofia Hartati ${ }^{2}$, Niken Pratiwi ${ }^{3}$ \\ 1,2,3 Universitas Negeri Jakarta, Indonesia \\ (*) $\square$ yuliani.nurani@unj.ac.id
}

\begin{abstract}
This research aimed to develop a set of effective communication based teaching skills for early childhood education teacher which evolved according to Indonesian National Curriculum Framework used recently in Early Childhood Education Department, Faculty of Education, Universitas Negeri Jakarta. The Research will be done in two years using research and development method.Literature review has been done concerning on effective communication and teaching skill for the first year and conducted a set of teaching skill indicators. Data are collected from early childhood education teachers in Jakarta related to theory and practice of teaching skill by observation, interview and performance test. The result of the research is indicators for early childhood education teachers' teaching skill. On the other hand, a draft of effective communication practicesis conducted to be implemented in teachers' teaching skill. Both of these concepts will be used to develop a model of effective communication based teaching skills for early childhood teacher. The result may become a consideration of the education institution of educators, researcher and government indeveloping training model to improve teachers' teaching skill.
\end{abstract}

Keywords: Teacher, teaching skill, effective communication, early childhood education

\section{Introduction}

An educational process through learning activities is central in fostering children's learning. These learning activities mediate active interactions between teachers and children. In this sense, teachers play an important role in children's learning. The success of their learning thus requires teachers' professionalism. Previous studies have shed light that teachers' performance and characteristics contributed to students' positive achievements significantly (Wenglinsky, 2002)

In an early childhood education, the demand for accountable and professional services is essential. Teachers who have a central role in education are required to satisfy a set of educational standards that encompasses pedagogical, professional, personality, and social standards. These standards indicate a quality threshold of Indonesian teachers. The Regulation number 16 year 2007 about Academic Qualification Standards and Teachers' Competences issued by the Indonesia's Ministry of Education explicitly governs the expectations for qualifications and competences of teachers of early childhood learning. This regulation also considers teaching skills as one of integral factors in achieving a quality education.

Copyright $\odot$ 2019, the Authors. Published by Redwhite Press.

This is an open access article under the CC BY-NC license

(http://creativecommons.org/licenses/by-nc/4.0). 
With respect to the importance of teaching skills, it is necessary to organize programs that can help improve these skills. It is argued that teachers' knowledge and skills as well as their thorough understanding in educating children that are in congruent with their unique developmental characteristics can support their optimum growth and development (Semiawan, 2002, p. 25). As a response to enhance teachers' professionalism, the article number 26 in the Regulation number 19 year 2005 about the National Standards of Education administers the requirements for teachers. Teachers thus are required to have qualifications that include both academic and competency qualifications. Teachers' competence includes pedagogical, personality, professional, and social competences. Academic qualification, on the other hand, is based on specific educational levels.

Teaching skills of early childhood in-service and pre-service teachers are varied. Previous study investigated the use of technology in assessing teaching skills. This study showed that the development of teaching skills can be monitored through a technology-based assessment tool (Nurani \&Utami, 2015). The results of this study have an implication on the development of a model related to teaching skills. The development of a teaching skills model for early childhood teachers that is based on the Effective Communication provides a wide range of opportunities for in-service and pre-service teachers in coping with possible constraints related to their teaching skills and activities. The Effective Communication is believed to support teachers in building an effective communication with children. By understanding children, teachers can help them enhance their optimum achievements. The development of this teaching skills model is necessary to improve teachers' pedagogical competences and learning quality as well as to offer an alternative paradigm moving away from a conventional paradigm in early childhood education. The development of this model involves early childhood teachers in Jakarta, educators, experts, and communication experts in order to gain a comprehensive result that is not only effective but also applicable and in congruent with the concept of early childhood education in Indonesia.

\section{Method}

This study used Research and Development (R\&D) design. Richey and Nelson point out that developmental research orientates itself towards product development whose process is thoroughly described and whose final product is evaluated (Richey dan Nelson, 1996). In the study, R\&D was utilized as a method to develop a product, i.e. a training design. This was done by first exploring problems faced by early childhood teacher candidates at early childhood teacher training institutions throughout Jakarta province so that the development of a model for effective-communication-based teaching skills can be constructed theoretically. Van den Akker views R\&D as a form of formative research, i.e. research which is conducted through a cyclical process and aimed at optimizing the quality of product application in a certain situation (Van den Akker, 1999). Results obtained from exploring the problems through theoretical and paraxial analyses concerning need assessment were then used as bases for designing the product. By so doing, a theoretically sound model of effectivecommunication-based teaching skills can be produced. To conform to the theory, the process of this R\&D study followed a cyclical pattern, starting from designing to testing the draft of the model followed by using effective communication approach that will be implemented through a practical experiment, discussion and consultation. Following the procedure, this study will produce a theoretically, methodologically, and empirically sound product.

The first phase of the research was concept analysis and expert validation followed by testing the product to see how it works in an instructional setting. The data obtained were used as the bases for designing and revising the model, resulting in a valid model. Classroom action research was carried out within instructional activities run by the teachers (Sugiyono, 2009). The development of the model for effective-communication-based teaching skills was a form of training for the student teachers as teacher candidates focused on the development of effective-communication-based teaching skills. The targets were pre-service teachers as teacher candidates and in-service teachers doing Bachelor of Early Childhood Education and taking Curriculum 1 (theory) and Curriculum 2 
(practice) subjects at the Department of Early Childhood Education, Faculty of Education, Universitas Negeri Jakarta (Jakarta State University), Jakarta.

This study employed both quantitative and qualitative data analyses. Quantitative analysis was called for analyzing descriptive scores obtained from assessing the concept which included assessment scores from the experts. This was then followed by qualitative analysis. Quantitative analyses were also carried out at each cycle of data obtained from observing teachers' teaching skills. To ensure its accountability, data triangulation was carried out. In this study, the researcher triangulated the data with the resources. Qualitative comparative analysis (QCA) was also conducted to see how the teachers' teaching skills improved when using the model as well as the suitability and applicability of the model to the teachers' teaching ability and the instructional setting.

\section{Results and Discussion}

The results of the research in teachers' effective communication based teaching skill development are conducting the criterion in indicators of effective communication based teaching skills. The criterion is divided in 8 aspects of teaching skill that determine the effective communication based teaching skills to be used in early childhood education settings.

Table 1. Indicators Early Childhood Teachers' Effective Communication Based Teaching Skill (McCarthy, 1990; Pramling Samuelsson \& Sheridan, 2010; Velentzas \& Broni, 2014; Yoon, Kim, Lee, and Jeon (2007)

\begin{tabular}{|c|c|c|}
\hline \multicolumn{3}{|c|}{$\begin{array}{l}\text { Effective communication based Teaching Skill } \\
\text { concept }\end{array}$} \\
\hline $\begin{array}{l}\text { Teaching Skill } \\
\text { Aspects }\end{array}$ & $\begin{array}{l}\text { Effective } \\
\text { Communicati } \\
\text { on Aspects }\end{array}$ & Indicators \\
\hline $\begin{array}{l}\text { Concept(philos } \\
\text { ophical, } \\
\text { historical, and } \\
\text { psychological) }\end{array}$ & Information & $\begin{array}{l}\text { Teacher understand } \\
\text { the concept in } \\
\text { student's teaching } \\
\text { and learning as the } \\
\text { information that will } \\
\text { be delivered }\end{array}$ \\
\hline $\begin{array}{l}\text { (development } \\
\text { and } \\
\text { implementatio } \\
\mathrm{n} \text { of the } \\
\text { curriculum) }\end{array}$ & & \\
\hline \multirow[t]{3}{*}{ Creativity } & Method & \\
\hline & & $\begin{array}{l}\text { Teacher determine } \\
\text { the method of } \\
\text { communication } \\
\text { according to child } \\
\text { characteristic } \\
\text { (application) }\end{array}$ \\
\hline & Tools & $\begin{array}{l}\text { Teacher design the } \\
\text { plan to do the } \\
\text { communication } \\
\text { process (synthesis) }\end{array}$ \\
\hline
\end{tabular}




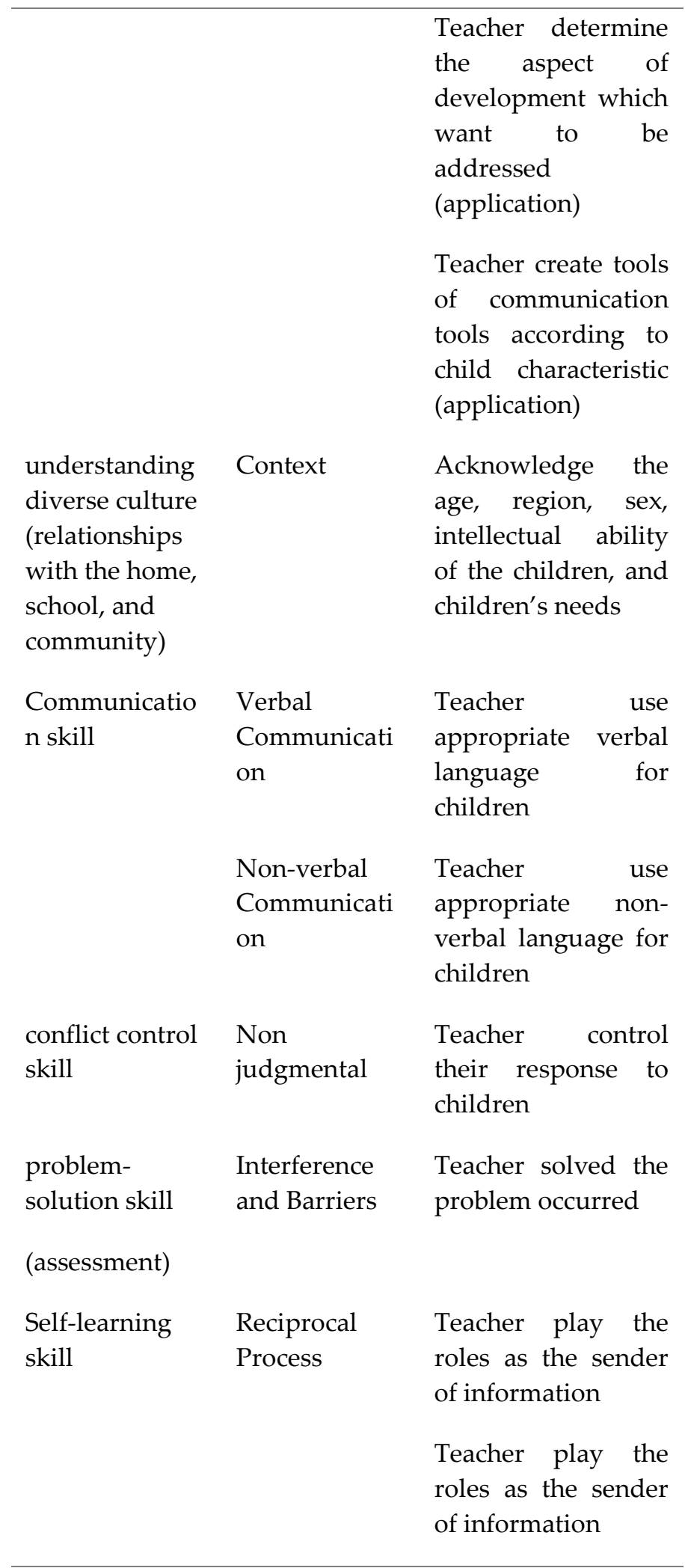

\section{Conclusions}

Based on the data obtained in the study, it showed that the use of technological devices,information and communication in Early Childhood Education Program, especially in the 
course curriculum of basic skills, teaching for theoretical and micro teaching and teaching practices from the beginning until the end of the lesson (macro teaching).

According Raju (2006: 36-37) and Supriyadi (2011:195) teacher must have teaching skills as follows:

1. Opening and Closing lesson

2. Explaination skills the lesson

3. Questioning skills

4. Managing the class

5. Activated student in class

6. Preparing class and instructional media

7. Evaluation and reporting

Effective Communication Skills Based Communication Module and Modelling can provide guidance for early childhood teachers in preparing learning activities and interact in the classroom Teachers have the skills to teach in accordance with the expected competencies.

\section{References}

[1] Adler, R., and Towne, N., "Looking out/looking in", (2nd ed.). New York: Holt, Rinehart and Winston, 1978.

[2] Cochran-Smith, M., \&Lytle, S.L., Relationships of knowledge and practice: Teacherlearning communities. Review of Research in Education", vol: 24, 249-305., 1999.

[3] Ford, J, Knight, J., \& McDonald-Littleton, E. (2001). Learning Skills: A comprehensiveorientation and study skills course designed for Tennessee Families First AdultEducation Classes, Knoxville: University of Tennessee, Knoxville Center for LiteracyStudies. Retrieved May 16, 2009, from http://www.cls.utk.edu/ls curriculum.html

[4] Jasim., A.," Teaching of Biological Science", New Delhi : PHI, 2009

[5] Kyriacou, Chris., "Essential Teaching Skill. Third Edition",' United Kingdom: Nelson Thornes Ltd., 2007.

[6] Lunenberg, FC., "Communication: The process, Barriers, and Improving Effectiveness", Schooling, Vol.1, 2010.

[7] McCarthy, J., "The content of early childhood education programs: Pedagogy", ed B., Spodek \& O.N. Saracho (Eds.), Early childhood teacher education: Yearbook in early childhood education (Vol. 1, pp. 82-101).' New York, NY: Teachers College Press., 1990.

[8] Rho, H., Park, S., Kwon, S.,"A Study on Early Childhood Teacher's Alternative Teaching Competency", Korean Journal of the Learning Sciences, 2014.

[9] Pramling Samuelsson, I., and S. Sheridan.," $A$ Turning-Point or a Backward Slide: The Challenge Facing the Swedish Preschool Today.Early Years 30 (3): 219-227, 2010.

[10] Richey, R.C., and Nelson. WA., "Developmental Research. In D.H. Jonassen (ed). Handbook of Research for Educational Communications and Technology", New York: Simon \& Schuster MacMillan, 1996.

[11] Semiawan, Conny. R., "Belajar dan Pembelajaran dalam Taraf Usia Dini",Jakarta: PT Ikrar Mandiri Abadi, 2002.

[12] Sheridan. S., Williams. P., Sandberg. A., and Vuorinen, T., "Preschool Teaching in Sweden- A Profession in Change, Educational Research Online) Journal, 2011.

[13] Sugiyono. "MetodePenelitianBisnis (PendekatanKuantitatif, Kualitatif, dan RED)", Bandung: Alfabeta, 2009 .

[14] Van den Akker, "Principles and Methods od Development Research. In van den Akker, R. Branch, K. Gustafson, N. Nieveen, and T. Plomp (Eds), Design approaches and tools in Education and Training “', Dordrecht: Kluwer Academic Publishers, 1999.

[15] Velentzas \& Broni, "Communication Cycle: Defenition, Process, Model and Example", Technological Institute of Western Macedonia, 2014 http://www.wseas.us/elibrary/conferences/2014/Istanbul

[16] Wenglinsky, H., "How Shools Matter: The Link Between Teacher Classroom Practices and Student Academic Performance", Eduaction Policy Analysis Archieve. (Online), 2002. http://epaa.asu.edu/epaa/v10n12/

[17] Wragg E.C. "Primary Teaching Skills", USA : Routledge, 2005.

[18] Yoon, H., Kim, Y., Lee, K., \& Jeon, J.. "A Study on Developing a Key Competence in thePrimary/Secondary School Curriculum for the Future of Koreans", KICE report, RRC2007-1., 2007.

[19] Yuliani, N., and Utami, AD., "Implementing ICT in Assessing Student's Teaching Skill", Educational Technology World Conference, 2015. 